\title{
Generalized Myasthenia Gravis Diagnosed After Blepharoplasty
}

\author{
Blefaroplasti Sonrası Tanı Alan Jeneralize Miyastenia Gravis
}

\author{
(1) Murat Alemdar, (1) Mustafa Karabacak \\ Sakarya University Faculty of Medicine, Department of Neurology, Sakarya, Turkey
}

\begin{abstract}
Neuromuscular junction disorders should not be missed in the differential diagnosis of ptosis. A 69-year-old male patient was admitted to our clinic with droopy upper eyelids, prominent in the left side for 6 months. Attributing his eyelid skin sag to aging, blepharoplasty was performed 5 months ago. He was referred to our department after no benefit was observed from operation. He reported difficulty in walking and climbing stairs, and getting fatigued while chewing food. In repetitive nerve stimulation studies, a significant decremental response was observed in the compound muscle action potential amplitudes recorded from the nasalis muscle with repetitive stimulation of the facial nerve on both sides, and the trapezius muscle with the stimulation of the left accessory nerve. Computed tomography of the thorax was normal. His serum acetylcholine receptor antibody level was elevated ( $40.7 \mathrm{nmol} / \mathrm{l})$. He was diagnosed as myasthenia gravis and pyridostigmine therapy was recommended. He described a definite improvement in his complaints ten days later on control visit. The history of this late-diagnosed patient presenting with ptosis emphasizes the importance of questioning additional findings like diplopia, chewing-swallowing difficulties, weakness in proximal muscles, and questioning whether there is an increase in those complaints due to fatigue.
\end{abstract}

Keywords: Blepharoptosis, myasthenia gravis, blepharoplasty

$\ddot{\mathbf{O} z}$

Pitozun ayırıcı tanısında nöromusküler kavşak hastalıkları atlanılmamalıdır. Polikliniğimize 69 yaşında bir erkek hasta, 6 aydır olan sol göz kapağında daha belirgin olmak üzere göz kapaklarında düşüklük nedeniyle başvurdu. Kapak derisinin yaşlanma nedeniyle sarktığ ifade edilerek, 5 ay önce blefaroplasti yapılmıştı. Operasyondan fayda görmeyince bölümümüze yönlendirilmişti. Yürüme ve merdiven çıkmada zorluk şikayetinin de olduğu, akşam yemeğini çiğnerken de yorulduğu öğrenildi. Repetetif sinir uyarım çalışmalarında; her iki tarafta fasiyal sinirin ardışı uyarımıyla nazalis kasından ve sol aksesuar sinirin uyarımıyla trapezius kasından kaydedilen bileşik kas aksiyon potansiyeli amplitütlerinde dekremental yanıt izlendi. Toraks tomografisi doğaldı. Serum asetilkolin reseptör antikor düzeyi artmıştı $(40,7 \mathrm{nmol} / \mathrm{l})$. Miyastenia gravis tanısı konulan hastaya piridostigmin tablet tedavisi önerildi. On gün sonraki kontrolünde hasta, şikayetlerinde belirgin düzelme tarifledi. Pitozla başvuran ve tanısı geç konulan hastamızın öyküsü, diplopi, çiğneme-yutma güçlüğü ve ekstremite proksimallerinde kuvvetsizlik gibi bulguların ve şikayetlerde yorulmakla artış olup olmadı̆̆ının sorgulanmasının önemini vurgulamaktadır.

Anahtar Kelimeler: Blefaropitoz, miyastenia gravis, blefaroplasti

\section{Introduction}

Ptosis is a congenital or acquired drooping of the upper eyelid (1). Low upper eyelid, which can cause functional and cosmetic problems, is more common in the elderly. Myogenic, neurogenic, mechanical, aponeurotic, or traumatic causes may underlie these acquired ptoses; however, neuromuscular junction diseases should be considered in the differential diagnosis of patients who present with this complaint. Physicians should question the findings, such as ptosis, diplopia, chewing-swallowing difficulty, and proximal extremity weakness, and consult the neurology department in suspicious cases. This presentation aimed to discuss a patient who was referred to our outpatient clinic with the complaint of ptosis that did not improve despite blepharoplasty and in whom the diagnosis of myasthenia gravis (MG) was delayed.

\section{Case Report}

A 69-year-old male patient was referred to our outpatient clinic with the complaint of droopy eyelids, which started approximately 6 months ago and persisted despite blepharoplasty. The patient was admitted to an ophthalmologist when the drooping of the left

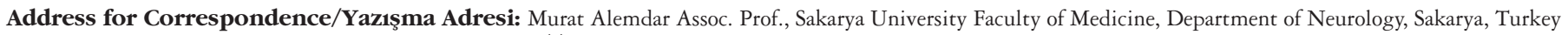
Phone: +90 5322032744 E-mail: dr.alemdar@gmail.com ORCID: orcid.org/0000-0001-7127-3119

Received/Gelis Tarihi: 03.05.2020 Accepted/Kabul Tarihi: 16.05.2020

${ }^{\circ}$ Copyright 2021 by Turkish Neurological Society

Turkish Journal of Neurology published by Galenos Publishing House. 
eyelid, which became evident in the evenings, caused difficulty in vision. He was told that his eyelid skin sagged due to aging, thus he underwent blepharoplasty approximately 5 months ago. Without improvement from the surgery, he was admitted to the ophthalmology clinic of our hospital and was referred to our department. His anamnesis revealed complaints of weakness, difficulty in walking and climbing stairs that became more evident in the last 2 months, and fatigue upon chewing during dinner. He did not describe any significant hoarseness or difficulty swallowing.

In the neurological examination, the patient was conscious, cooperative, and oriented. His pupils were normoisochoric. Direct and indirect light reflexes were normoactive. Bilateral ptosis $(\sim 3$ $\mathrm{mm}$ ) was observed at rest, which was more prominent on the left (Figure 1a). The infraduction in the right eye was partially limited. Eye movements were otherwise normal. Examination of other cranial nerves was unremarkable. The muscle strength examination according to Medical Research Council scale revealed the following: neck flexors were $4 / 5$, neck extensors were $5 / 5$, left upper extremity shoulder elevators and abductors at $4 / 5$, other proximal muscles $-5 / 5$, right upper extremity proximal muscles were $-5 / 5$, and distal muscles were $5 / 5$. The strength of the lower extremity proximal and distal muscles was $5 / 5$. Sensory deficit was not observed. Deep tendon reflexes were normoactive in all four extremities. Plantar reflexes were bilaterally flexor. Cerebellar tests were normal. The patient's ptosis became evident after the fatigue test was performed by letting the patient look up for $1 \mathrm{~min}$ (Figure 1b).

The repetitive nerve stimulation studies performed in our electromyography (EMG) laboratory revealed significant decremental response in compound muscle action potential (CMAP) amplitudes that were recorded from the nasalis muscle with $3 \mathrm{~Hz}$ repetitive stimulation of the facial nerve on both sides and the trapezius muscle with the stimulation of the left accessory nerve. CMAP amplitude measurements revealed a decrement in the left nasal muscle by $47.4 \%$, in the right nasal muscle by $24.5 \%$, and in the left trapezius muscle by $10.4 \%$ at the fourth stimulation compared to the first CMAP. Thorax computed tomography was normal. The serum acetylcholine receptor antibody level was 40.7 $\mathrm{nmol} / \mathrm{l}$ (threshold value of $<0.4 \mathrm{nmol} / \mathrm{l}$ ). Pyridostigmine treatment was recommended to the patient who was diagnosed with MG. At the 10-day follow-up, he described a significant improvement in his complaints. Informed consent was obtained from the patient.

\section{Discussion}

Ptosis results from dysfunction of the superior levator palpebrae or Müller's muscles, which are responsible for retracting the upper eyelid, which can be mild (1-2 mm), moderate $(3-4 \mathrm{~mm})$, and advanced $(>4 \mathrm{~mm}$ ) and may cause a tired face and advanced visual difficulties (2). Blepharoplasty operations, in which excess skin and adipose tissue in the upper eyelid is removed, are performed to achieve a younger appearance. In addition to this procedure, the junction of the aponeurosis of the levator palpebrae muscle at the tarsal base is changed in patients with MG (3). Ptosis and diplopia are the first manifestations that are observed in $>50 \%$ of patients with MG (4), wherein $50 \%-80 \%$ progress to generalized MG (5). Conversion to generalized MG occurs within the first 2 years after the onset of ptosis and other ocular manifestations in 90\% of progressive patients (6). In patients with acquired ptosis, as in

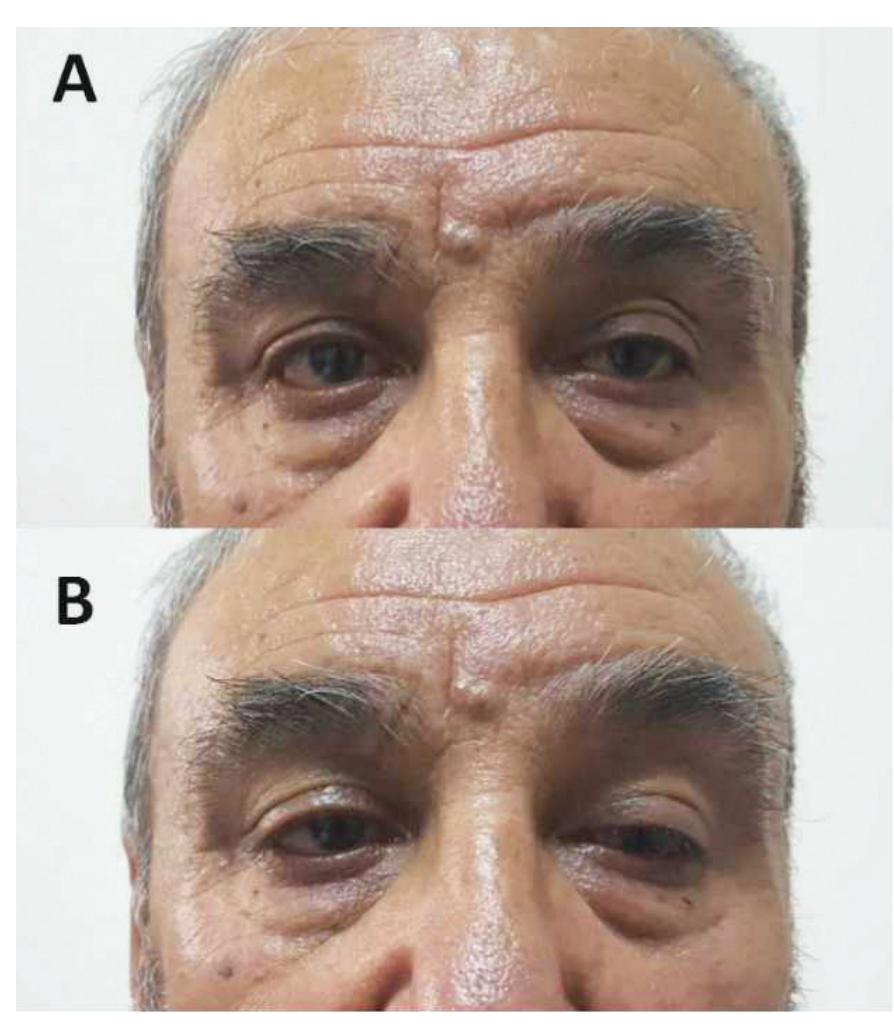

Figure 1a. Bilateral mild ptosis of the patient at rest, more prominent on the left, $\mathbf{b}$. Ptosis that became evident after the fatigue test that was performed by letting the patient look up for $1 \mathrm{~min}$

our patient, ptosis and muscle fatigue, which increase with fatigue or later in the day, should be questioned with a good anamnesis and auxiliary clinical tests, such as fatigue test or ice test $(7,8)$. EMG that is performed for neuromuscular junction diseases in suspected patients and laboratory investigations are essential for both confirmation of diagnosis and appropriate management.

In patients with $\mathrm{MG}$, blepharoplasty can be performed in the late period when the patient becomes clinically stable and if the existing ptosis does not respond to optimal medical treatment. Anesthesia management is important in patients in whom surgery is required due to ptosis or other reasons. Regional anesthesia or peripheral nerve blocks are preferred in most surgeries today; however, general anesthesia and muscle relaxation are required in some patients. In these patients, a large variability is found in the sensitivity to nondepolarizing muscle relaxants, as well as drug hypersensitivity. The duration of the neuromuscular block may be prolonged and even mechanical ventilators may be necessary due to the prolonged postoperative effect (9). The possibility of developing anesthesia-related complications is even higher, especially in surgeries that require muscle relaxation. Therefore, patients with MG who require blepharoplasty must have an optimized medical treatment in the preoperative period and anesthesia management should be carefully performed during the operation. However, myasthenic patients with ptosis respond well to medical treatment most of the time, and should be referred to the neurology department for correct diagnosis and avoidance of surgical interventions that may worsen the disease and pose a life- 
threatening risk.

\section{Conclusion}

In conclusion, our patient highlighted the importance of questioning the presence of additional findings, such as diplopia, chewing-swallowing difficulties, proximal extremity weakness, and increased complaints due to fatigue in patients presenting with ptosis. A detailed anamnesis is important both for accurate diagnosis and appropriate treatment and for avoiding unnecessary surgical interventions.

\section{Ethics}

Informed Consent: Informed consent was obtained from the patient.

Peer-review: Externally and internally peer-reviewed.

\section{Authorship Contributions}

Concept: M.A., M.K., Design: M.A., M.K., Data Collection or Processing: M.A., M.K., Analysis or Interpretation: M.A., M.K., Literature Search: M.A., M.K., Writing: M.A.

Conflict of Interest: The authors have not declared any conflict of interest related to this article.
Financial Disclosure: No financial support was received from any institution or person for our study.

\section{References}

1. Patel K, Carballo S, Thompson L. Ptosis. Dis Mon 2017;63:74-79.

2. Finsterer J. Ptosis: causes, presentation, and management. Aesthetic Plast Surg 2003;27:193-204

3. Kwitko GM, Patel BC. Blepharoplasty Ptosis Surgery. 2021. In: StatPearls [Internet]. Treasure Island (FL): StatPearls Publishing; 2021.

4. Grob D, Arsura EL, Brunner NG, Namba T. The course of myasthenia gravis and therapies affecting outcome. Ann N Y Acad Sci 1987;505:472-99.

5. Antonio-Santos AA, Eggenberger ER. Medical treatment options for ocular myasthenia gravis. Curr Opin Ophthalmol 2008;19:468-478.

6. Oosterhuis HJ. Observations of the natural history of myasthenia gravis and the effect of thymectomy. Ann N Y Acad Sci 1981;377:678-690.

7. Gorelick PB, Rosenberg M, Pagano RJ. Enhanced Ptosis in Myasthenia Gravis. Arch Neurol 1981;38:531

8. Nair AG, Patil-Chhablani P, Venkatramani DV, Gandhi RA. Ocular myasthenia gravis: a review. Indian J Ophthalmol 2014;62:985-991.

9. Erkal H, Özyurt Y, Arikan Z. Myasthenia Gravis and anesthesia: a case report. Bakırköy Tip Dergisi 2006;2:141-131. 